\title{
UNIAXIAL DYNAMIC MECHANICAL PROPERTIES OF TUNNEL LINING CONCRETE UNDER MODERATE-LOW STRAIN RATE AFTER HIGH TEMPERATURE
}

\author{
L. X. XIONG
}

\begin{abstract}
To investigate the mechanical properties of tunnel lining concrete under different moderate-low strain rates after high temperatures, uniaxial compression tests in association with ultrasonic tests were performed. Test results show that the ultrasonic wave velocity and mass loss of concrete specimen begin to sharply drop after high temperatures of $600{ }^{\circ} \mathrm{C}$ and $400{ }^{\circ} \mathrm{C}$, respectively, at the strain rates of $10-5 \mathrm{~s}-1$ to $10-2 \mathrm{~s}-1$. The compressive strength and elastic modulus of specimen increase with increasing strain rate after the same temperature, but it is difficult to obtain an evident change law of peak strain with increasing strain rate. The compressive strength of concrete specimen decreases first, and then increases, but decreases again in the temperatures ranging from room temperature to $800 \square \mathrm{C}$ at the strain rates of $10-5 \mathrm{~s}-1$ to $10-2 \mathrm{~s}-1$. It can be observed that the strain-rate sensitivity of compressive strength of specimen increases with increasing temperature. In addition, the peak strain also increases but the elastic modulus decreases substantially with increasing temperature under the same strain rate.
\end{abstract}

Keywords: concrete, high temperature, strain rate, mechanical properties

\section{INTRODUCTION}

Fire resistance is one of the main issues that must be considered in tunnel design. A number of tunnel fire accidents have shown that fire can result in extensive and severe damages to concrete tunnel linings (Schrefler et al. [1]).

\footnotetext{
${ }^{1}$ Associate Prof., PhD., Eng., Ningbo University, Faculty of Architectural, Civil Engineering and Environment, Ningbo, Fenghua Road 818, PR China, e-mail: xionglx1982@126.com
} 
These damages involve mechanical properties degradation, thickness reduction of linings due to spalling, and generation of local stresses due to no uniform thermal strains, which can severely reduce the concrete lining safety, threaten future safe operation and even cause the tunnel lining collapse (Yan et al. [2]). Therefore, the study on the mechanical damage behaviour of lining concrete in fire has both theoretical and practical significance on improvement of tunnel lining's fire safety.

Many researchers have conducted tests on the post-fire mechanical properties of concrete. Chan et al. [3] carried out an experiment which studied the mechanical properties and pore structure of high-performance concrete and normal-strength concrete after exposure to high temperatures. Poon et al. [4] compared the strength and durability performance of normal-strength and highstrength pozzolanic concretes with silica fume, fly ash, and blast furnace slag at elevated temperatures of up to $800^{\circ} \mathrm{C}$. Li et al. [5] investigated the mechanical properties of normal-strength concrete and high-strength concrete after high temperatures. Xiao \& Konig [6] summarized the states-of-the-art studies on the mechanical behaviors of concrete at high temperature in China. Chang et al. [7] performed an experimental investigation on the complete compressive stress-strain relationship for concrete after heating to temperatures of $100-800{ }^{\circ} \mathrm{C}$. Husem [8] examined the variation of compressive and flexural strengths of ordinary and high-performance microconcrete at high temperatures. Chen et al. [9] investigated the effects of curing age, type of cooling and the maximum temperature on the relative recovered strengths of concrete after exposure to high temperatures. He \& Song [10] performed multiaxial tensile-compressive tests on cubic specimens of plain high-performance concrete (HPC) at various different stress ratios after the tested specimens were exposed to elevated temperatures. Tai et al. [11] presented a series of experiments which investigated the mechanical properties of RPCs after exposure to high temperatures. Zheng et al. [12] performed an experimental study on the complete compressive stress-strain relationships for reactive powder concrete (RPC) with various steel fiber contents after exposure to $20-900{ }^{\circ} \mathrm{C}$, Recently, Luigi et al. [13] described the consequences of progressive damage in architectural high performance concrete when exposed to different heat treatments. Marques et al. [14] investigated the effects of elevated temperatures on the residual mechanical performance of concrete produced with recycled rubber aggregate. More recently, Tahir [15] investigated the influence of the specimen size on the behaviour of engineered cementations composite specimens exposed to elevated temperatures. The above literature survey shows that, despite the large number of publications on the mechanical properties of concrete during or after its exposure to elevated 
temperatures, little research work has been focused on the dynamic mechanical properties of concrete during or after its exposure to elevated temperatures.

For many concrete structures such as tunnels and buildings, it is expected that they could continue to be in service after a fire. These structures may also encounter seismic loads during the follow-up service lifetime. Thus, it is necessary to study the dynamic mechanical properties of concrete when or after they are exposed to elevated temperatures.

Currently, there are few researchers who studied the dynamic mechanical properties of concrete after high temperature exposure.. Li et al. [16] carried out quasi-static and impact loading experiments on concrete before and after exposure to a high temperature. Huo et al. [17] carried out impact tests using a SHPB bar to experimentally study the dynamic behaviours of concrete after exposure to high temperatures. Su et al. [18] studied the dynamic compressive mechanical properties of concrete at elevated temperatures using a self-designed high temperature SHPB apparatus. The strain rates used in these tests weremuch higher, normally about $30 \mathrm{~s}^{-1}$ to $200 \mathrm{~s}^{-1}$. These tests mainly examined the dynamic mechanical properties of concrete under impact or blast loading. However, for seismic loading the strain rate is usually between $10^{-3} \mathrm{~s}^{-1}$ and $10^{-2} \mathrm{~s}^{-1}$ for studying the dynamic performance of concrete (Shi et al. [19]).

In this study, ultrasonic test and uniaxial compression test were performed to investigate the mechanical properties of concrete under different moderate strain rates after high temperature exposure. The strain rates adopted in the tests were between $10^{-5} \mathrm{~s}^{-1}$ to $10^{-2} \mathrm{~s}^{-1}$.

\section{EXPERIMENTAL PROGRAM}

\subsection{SPECIMEN PREPARATION}

The compressive strength grade of concrete specimens used is $\mathrm{C} 40$. The mean value of compressive strength of $\mathrm{C} 40$ concrete after curing for 28 days is $42.5 \mathrm{MPa}$. The size of concrete specimens is $100 \times 100 \times 100 \mathrm{~mm}^{3}$. A total of 64 specimens were modelled and tested.

No. 425 cement employed in this test was normal cement produced by the China Building Materials Academy. The ISO standard sand was used in accordance with the Chinese National Standard, and its particle size ranges from $0.5 \mathrm{~mm}$ to $1.0 \mathrm{~mm}$. The particle size of coarse aggregate ranges from $5 \mathrm{~mm}$ to $20 \mathrm{~mm}$. Table 1 shows the mixtures of the concrete specimens. 
Table 1. Mixtures of concrete specimens

\begin{tabular}{|c|c|c|c|}
\hline $\begin{array}{c}\text { Cement } \\
\left(\mathrm{kg} / \mathrm{m}^{3}\right)\end{array}$ & $\begin{array}{c}\text { Water } \\
\left(\mathrm{kg} / \mathrm{m}^{3}\right)\end{array}$ & $\begin{array}{c}\text { Sand } \\
\left(\mathrm{kg} / \mathrm{m}^{3}\right)\end{array}$ & $\begin{array}{c}\text { Coarse aggregate } \\
\left(\mathrm{kg} / \mathrm{m}^{3}\right)\end{array}$ \\
\hline 382 & 141.34 & 637.94 & 958.82 \\
\hline
\end{tabular}

\subsection{TABLES TEST PROCEDURE}

The ultrasonic wave velocities of specimens were measured using ultrasonic detector after being properly cured for 28 days. Then these specimens were elevated to the peak temperatures of 200 , 400,600 , and $800^{\circ} \mathrm{C}$ at the heating rate of $20^{\circ} \mathrm{C} / \mathrm{min}$, respectively. After the peak temperature was reached, it was maintained for another $2 \mathrm{~h}$; then the specimens were cooled down to room temperature in the furnace and then taken out for testing.

The ultrasonic wave velocities of these specimens were measured after 7 days, and then uniaxial compression tests were performed using WAW-600C universal testing machine. The maximum loading rate of the testing machine is $60 \mathrm{~mm} / \mathrm{min}$, and the maximum compression load is $600 \mathrm{kN}$ Four strain rates were used in the uniaxial compression tests, which are $10^{-2} \mathrm{~s}^{-1}, 10^{-3} \mathrm{~s}^{-1}, 10^{-4} \mathrm{~s}^{-1}$ and $10^{-5} \mathrm{~s}^{-1}$.

Three specimens were tested for each temperature and strain rate. The results of compressive strength, peak strain and elastic modulus are the average values of the three tested specimens, which will be discussed in detail in following section.

\section{TEST RESULTS AND ANALYSIS}

\subsection{THE CHANGE OF APPEARANCE CHARACTERISTICS OF SPECIMENS}

The changes of appearance characteristics of specimens after $200,400,600$, and $800^{\circ} \mathrm{C}$ are shown in Figs. 1-4. 


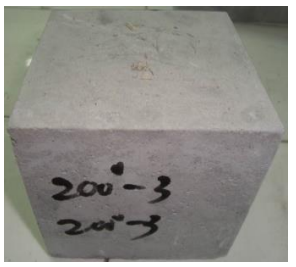

(a) before high temperature

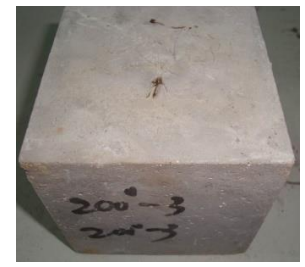

(b) after high temperature

Fig.1. The change of appearance characteristics of specimen after $200^{\circ} \mathrm{C}$

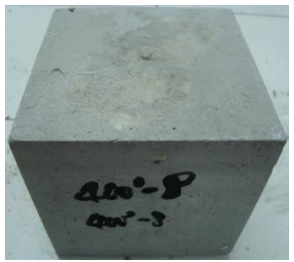

(a) before high temperature

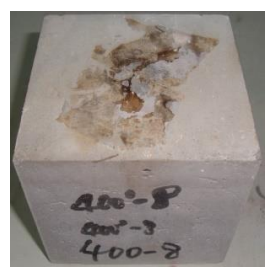

(b) after high temperature

Fig.2. The change of appearance characteristics of specimen after $400^{\circ} \mathrm{C}$

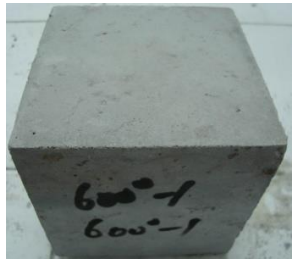

(a) before high temperature

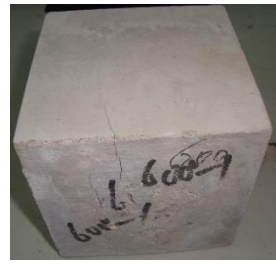

(b) after high temperature

Fig.3. The change of appearance characteristics of specimen after $600^{\circ} \mathrm{C}$

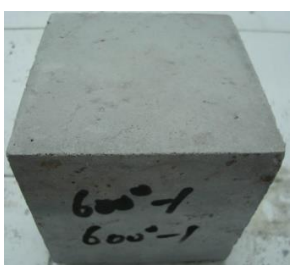

(a) before high temperature

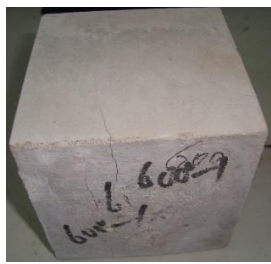

(b) after high temperature

Fig.4. The change of appearance characteristics of specimen after $800^{\circ} \mathrm{C}$ 
The number of specimens which experienced high temperature, and the number of specimens which had surface cracks after each temperature are presented in Table 2.

Table 2. The number of samples before high temperature and the number of samples which had surface cracks after high temperature

\begin{tabular}{|c|c|c|}
\hline Temperature $\left({ }^{\circ} \mathrm{C}\right)$ & $\begin{array}{c}\text { Number of samples before high } \\
\text { temperature }\end{array}$ & $\begin{array}{c}\text { Number of samples having } \\
\text { surface cracks after high } \\
\text { temperature }\end{array}$ \\
\hline 200 & 12 & 0 \\
\hline 400 & 12 & 6 \\
\hline 600 & 12 & 16 \\
\hline 800 & 16 & 6 \\
\hline
\end{tabular}

The specimens after $200{ }^{\circ} \mathrm{C}$ have no apparent cracks; only one of the specimens after $400{ }^{\circ} \mathrm{C}$ has apparent cracks; about half of the specimens after $600{ }^{\circ} \mathrm{C}$ have apparent cracks; all the specimens after $800{ }^{\circ} \mathrm{C}$ have apparent cracks.

\subsection{THE CHANGE OF ULTRASONIC WAVE VELOCITIES OF SPECIMENS}

The distribution of ultrasonic wave velocities of specimens before being exposed to high temperatures is listed in Table 3.

Table 3. The distribution of ultrasonic wave velocities of specimens before high temperature

\begin{tabular}{|c|c|}
\hline $\begin{array}{c}\text { Ultrasonic wave velocity range } \\
(\mathrm{m} / \mathrm{s})\end{array}$ & Number of specimen \\
\hline $4700-4800$ & 21 \\
\hline $4800-4900$ & 27 \\
\hline $4900-5000$ & 10 \\
\hline $5000-5100$ & 1 \\
\hline $5200-5300$ & \\
\hline
\end{tabular}


There were 64 specimens before high temperature in total, and the number of specimens with ultrasonic wave velocities ranging from about $4800 \mathrm{~m} / \mathrm{s}$ to $5000 \mathrm{~m} / \mathrm{s}$ accounted for $75 \%$ of the total samples. Therefore, it can be noted that minor difference in the specimens is observed.

In contrast, the ultrasonic wave velocities of the specimens before and after heating is shown in Fig. 5 .

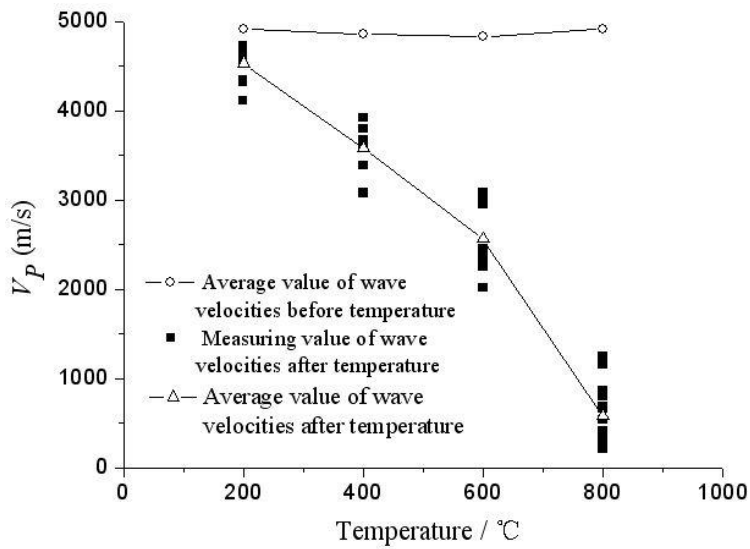

Fig. 5. The contrast of ultrasonic wave velocities of specimens before and after high temperature

It can be seen from the figure that, from room temperature to $200^{\circ} \mathrm{C}$, the variation of the ultrasonic wave velocity of specimen is not evident. From $200{ }^{\circ} \mathrm{C}$ to $400{ }^{\circ} \mathrm{C}$, the decreasing extent of the ultrasonic wave velocity of specimen is similar to that from $400{ }^{\circ} \mathrm{C}$ to $600{ }^{\circ} \mathrm{C}$. While, the decreasing extent of the ultrasonic wave velocity of specimen from $600{ }^{\circ} \mathrm{C}$ to $800{ }^{\circ} \mathrm{C}$ is the greatest.

The damage index of concrete exposed to high temperature can be given as the function of ultrasonic wave velocity:

$$
D=1-\left(1-\frac{V_{P T}}{V_{P}}\right)^{2}
$$

Where $D$ is the damage index, $V_{\mathrm{P}}$ is the initial ultrasonic wave velocity of specimen before being exposed to high temperature, and $v_{\mathrm{t}}$ is the ultrasonic wave velocity of specimen after being exposed to high temperature. 
The variation of damage index associated with temperature is shown in Fig. 6.

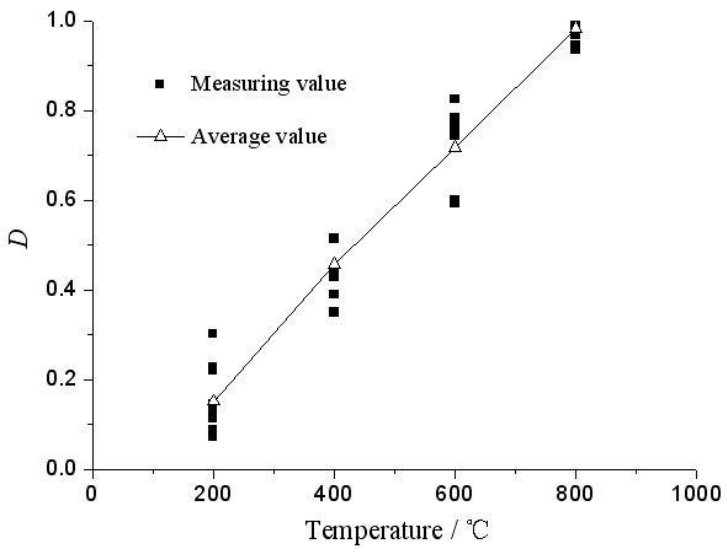

Fig. 6. The evolution of damage index

It can be seen from Fig.6 that, the damage index gradually increases linearly with increasing temperature. The values of damage index after being exposed to high temperatures of $200,400,600$, and $800{ }^{\circ} \mathrm{C}$ are $0.15127,0.45675,0.71802$ and 0.98412 , respectively.

\subsection{THE CHANGE OF MASS LOSS}

The mass loss of specimen can be defined as

$$
M_{c}=\frac{m_{0}-m_{T}}{m_{0}} \times 100 \%
$$

Where $M_{\mathrm{c}}$ is the mass loss, $m_{0}$ is the initial mass of specimen before exposed to high temperature, and $\mathrm{mT}$ is the mass of specimen after exposed to high temperature.

The evolution of mass loss with the temperature is shown in Fig. 7. 


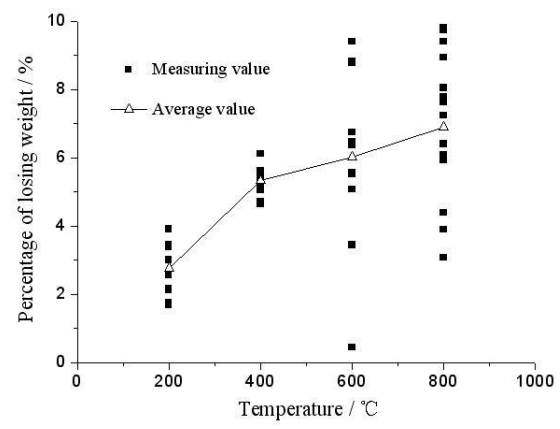

Fig. 7. The evolution of mass loss of concrete specimen with temperature

It can be seen from the figure that, from room temperature to $400^{\circ} \mathrm{C}$, the mass loss increases rapidly with increasing temperature. In contrast, from $400^{\circ} \mathrm{C}$ to $800^{\circ} \mathrm{C}$, the mass loss increases slowly with increasing temperature.

\subsection{THE VARIATION OF STRESS-STRAIN CURVES}

The influence of strain rate on the stress-strain curve of the specimen for the same temperature is displayed in Fig. 8 .

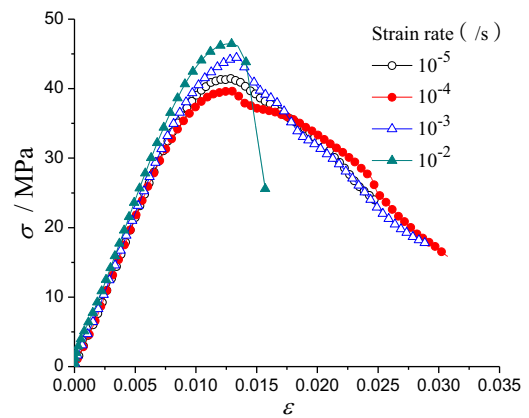

(a)Under room temperature

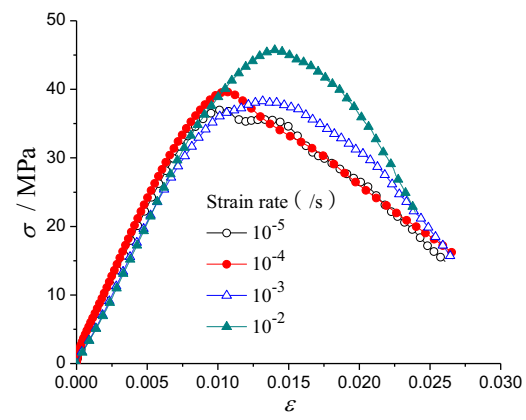

(b) Under $200^{\circ} \mathrm{C}$

Fig. 8. The influence of strain rate on the stress-strain curve of specimen when the temperature is the same 


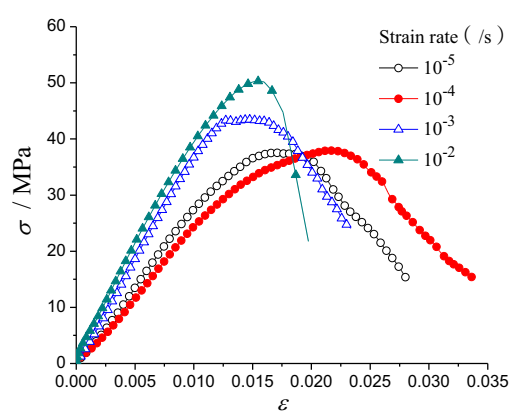

(c) Under $400^{\circ} \mathrm{C}$

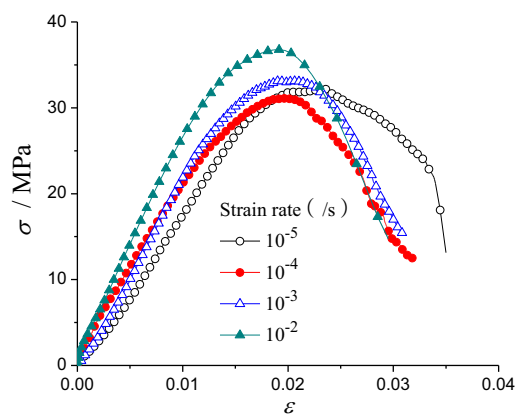

(d) Under $600^{\circ} \mathrm{C}$

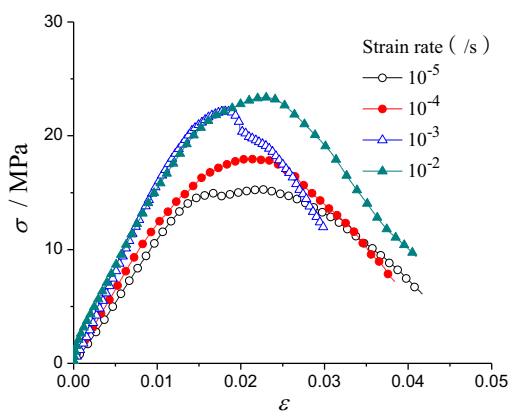

(e) Under $600^{\circ} \mathrm{C}$

Fig. 8. The influence of strain rate on the stress-strain curve of specimen when the temperature is the same - continued

The peak stress of specimen increases substantially with increasing strain rate regardless of the temperature experienced according to Fig.8. The slopes of softening stages of stress-strain curves of not-heated specimen and specimens after high temperature of $200^{\circ} \mathrm{C}$ and $400^{\circ} \mathrm{C}$, under strain rate of $10^{-2} \mathrm{~s}^{-1}$ are higher than those under other strain rates. The slopes of softening stages of stress-strain curves of specimens after high temperature of $600^{\circ} \mathrm{C}$ and $800^{\circ} \mathrm{C}$ under strain rate of $10^{-2} \mathrm{~s}^{-1}$ are similar to those under other strain rates, and are relatively flat. This suggests that the ductility of the specimen is improved at the temperatures of $600^{\circ} \mathrm{C}$ and $800^{\circ} \mathrm{C}$.

The influence of temperature on the stress-strain curve of the specimens when the strain rate is the same is shown in Fig. 9. 


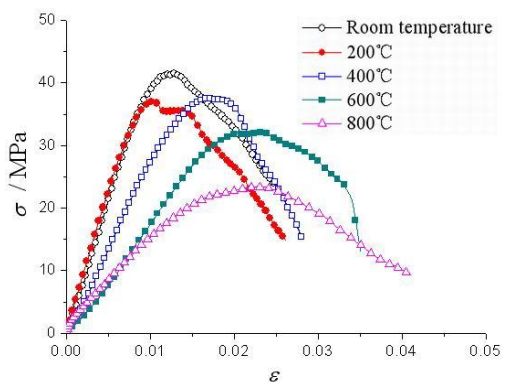

(a) Strain rate of $10^{-5} \mathrm{~s}^{-1}$

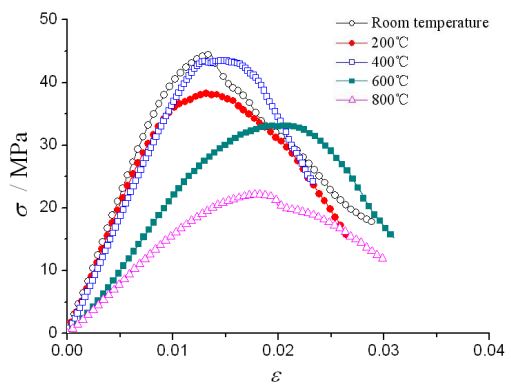

(c) Strain rate of $10^{-3} \mathrm{~s}^{-1}$

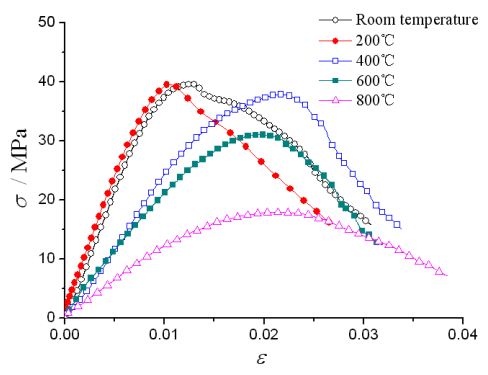

(b) Strain rate of $10^{-4} \mathrm{~s}^{-1}$

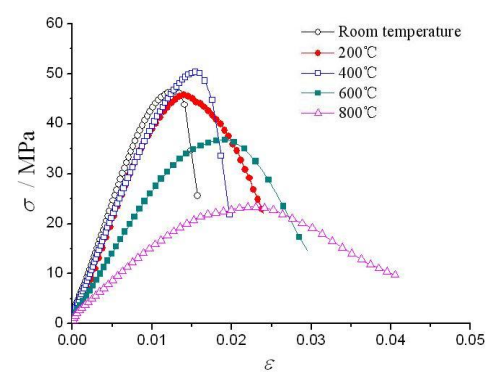

(d) Strain rate of $10^{-2} \mathrm{~s}^{-1}$

Fig. 9. The influence of temperature on the stress-strain curve of specimen when the strain rate is the same

\subsection{THE EVOLUTION OF COMPRESSIVE STRENGTH}

The evolution of the compressive strength is illustrated in Fig. 10.

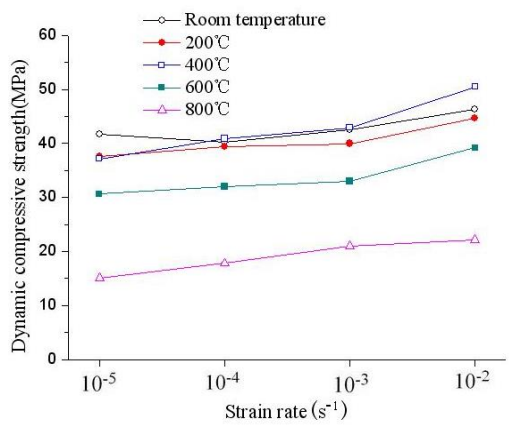

Fig. 10. The evolution of compressive strength 
The compressive strength of the specimens decreases from room temperature to $200^{\circ} \mathrm{C}$ under the same strain rate. However, the strength increases from $200^{\circ} \mathrm{C}$ to $400^{\circ} \mathrm{C}$. There is a decrease of the compressive strength to larger extent from $400^{\circ} \mathrm{C}$ to $800^{\circ} \mathrm{C}$.

The dynamic increase factor (DIF) for the compressive strength could be defined as:

$$
D I F=f_{c d} / f_{c s}
$$

where $D I F$ is the dynamic increase factor, $f_{\mathrm{cd}}$ is the compressive strength of concrete specimen at current strain rate, and $f_{\mathrm{cs}}$ is the compressive strength of concrete specimen at quasi-static strain rate. The quasi-static strain rate is taken as $10^{-5} \mathrm{~s}^{-1}$ in this study.

The relationship between the dynamic increase factor (DIF) and the current strain rate can be described by

$$
D I F=a+b \log _{10}\left(\dot{\varepsilon} / \dot{\varepsilon}_{0}\right)
$$

where $a$ and $b$ are the fitting parameters, and $\dot{\varepsilon}$ is the current strain rate. $\dot{\varepsilon}_{0}$ is the reference strain rate and can be set as $1 \mathrm{~s}^{-1}$. The parameter $b$ is the slope of the fitting line, reflecting the sensitivity of compressive strength on the strain rate.

The relationships between the dynamic increase factor (DIF) and the stain rate of specimens are shown in Fig. 11.

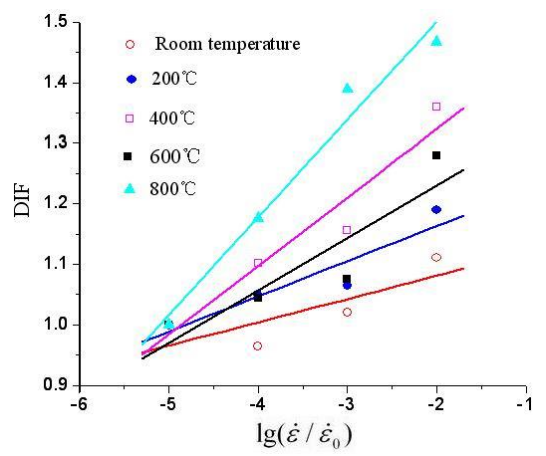

Fig. 11. Relation between strength increasing factor and stain-rate 
The relations between DIF and strain rate can be described as Eq. (3.5)-(3.9).

$$
\begin{aligned}
& \text { Room temperature: } D I F=1.15883+0.0386 \log _{10}\left(\dot{\varepsilon} / \dot{\varepsilon}_{0}\right) \\
& \mathrm{T}=200^{\circ} \mathrm{C}: D I F=1.27981+0.0582 \log _{10}\left(\dot{\varepsilon} / \dot{\varepsilon}_{0}\right) \\
& \mathrm{T}=400^{\circ} \mathrm{C}: D I F=1.55005+0.1132 \log _{10}\left(\dot{\varepsilon} / \dot{\varepsilon}_{0}\right) \\
& \mathrm{T}=600^{\circ} \mathrm{C}: D I F=1.40342+0.08679 \log _{10}\left(\dot{\varepsilon} / \dot{\varepsilon}_{0}\right) \\
& \mathrm{T}=800^{\circ} \mathrm{C}: D I F=1.82428+0.16169 \log _{10}\left(\dot{\varepsilon} / \dot{\varepsilon}_{0}\right)
\end{aligned}
$$

The value of $b$ increases substantially with increasing temperature. The increment of the value of $b$ is very evident from $600{ }^{\circ} \mathrm{C}$ to $800{ }^{\circ} \mathrm{C}$. The compressive strength is found to decrease with increasing temperature, thus the strain-rate sensitivity of compressive strength of specimen will increase with increasing temperature. This result is different from that attained by Li et al. [16].

\subsection{THE EVOLUTION OF PEAK STRAIN}

The evolution of compressive strength is shown in Fig. 12.

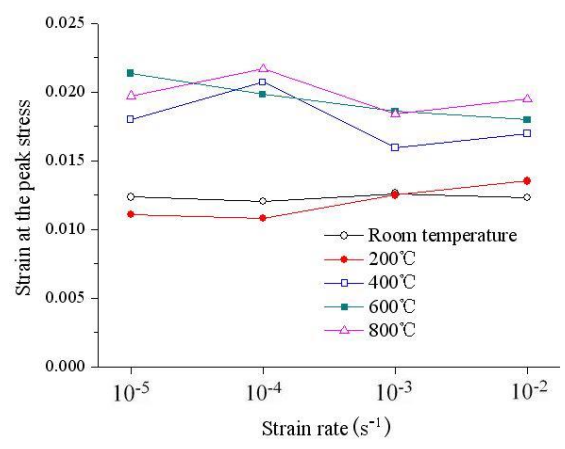

Fig. 12. The evolution of peak strain

There is slight change of peak strains of not-heated specimens and specimens after high temperature of $200^{\circ} \mathrm{C}$ with increasing strain rate. The peak strain of specimens after high temperature of $400^{\circ} \mathrm{C}$ decreases with increasing strain rate. The peak strains of specimens after high temperature of $600^{\circ} \mathrm{C}$ 
and $800^{\circ} \mathrm{C}$ first increase and then in general decrease with increasing strain rate. The peak strain of specimens tends to increase by increasing temperature under the same strain rate.

\subsection{THE EVOLUTION OF ELASTIC MODULUS}

The elastic modulus is calculated as a secant modulus in this study. The secant modulus is calculated from the origin to a defined point on the stress-strain curve, within $30 \%$ of the specimen's peak stress.

The evolution of elastic modulus is shown in Fig. 13.

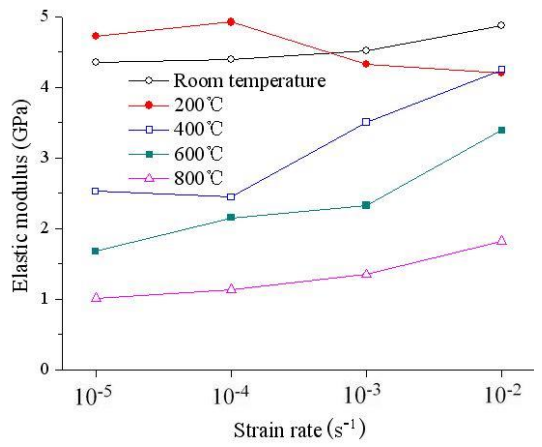

Fig. 13. The evolution of elastic modulus

The elastic modulus of specimens increases substantially with increasing strain rate after exposure to the same high temperature. However, the elastic modulus of specimens decreases substantially with increasing temperature under the same strain rate.

\section{Conclusions}

1. The surfaces of specimens after temperature of $600{ }^{\circ} \mathrm{C}$ begin to have lots of apparent cracks, and the ultrasonic wave velocity of specimens begins to decrease greatly after temperature of $600{ }^{\circ} \mathrm{C}$. The mass loss increases slowly with increasing temperature from $400^{\circ} \mathrm{C}$ to $800^{\circ} \mathrm{C}$.

2. The peak stress of specimens increases substantially with increasing strain rate regardless of the temperature experienced. The compressive strength of specimens decreases from room temperature to $200^{\circ} \mathrm{C}$, increases from $200^{\circ} \mathrm{C}$ to $400^{\circ} \mathrm{C}$, and decreases again from $400^{\circ} \mathrm{C}$ to $800^{\circ} \mathrm{C}$ 
under the same strain rate. The strain-rate sensitivity of compressive strength of specimen increases with increasing temperature.

3. There is no fixed change law for peak strain of specimens with increasing strain rate after the same temperature. But the peak strain of specimens is found to increase with increasing temperature under the same strain rate.

4. The elastic modulus of specimens increases substantially with increasing strain rate after the same high temperature. However, the elastic modulus of specimens decreases substantially with increasing temperature under the same strain rate.

\section{ACKNOWLEDGMENTS}

This work was supported by the Natural Science Foundation of Zhejiang Province (Grant No. LY13E080021), the Ningbo Municipal Natural Science Foundation (Grant No.2011A610072), the Project(Grant No. XKL14D2063) Subject Program of Ningbo University, and the Open Project (Grant No. 2014ZDK009) of Guangxi Key Laboratory of Disaster Prevention and Structural Safety.

\section{REFERENCES}

1. B. A. Schrefler, P. Brunello, D. Gawin, C. E. Majorana, F, "Pesavento Concrete at high temperature with application to tunnel fire", Computational Mechanics 29: 43-51, 2002.

2. Z. G. Yan, H. H. Zhu, J. W. Ju, "Behavior of reinforced concrete and steel fiber reinforced concrete shield TBM tunnel linings exposed to high temperatures", Construction and Building Materials 38: 610-618, 2013.

3. Y. N. Chan, X. Luo, W. Sun, "Compressive strength and pore structure of high-performance concrete after exposure to high temperature up to $800^{\circ} \mathrm{C}$ ", Cement and Concrete Research 30: 247-251, 2000.

4. C. S. Poon, S. Azhar, M. Anson, Y. L. Wong, "Comparison of the strength and durability performance of normal- and high-strength pozzolanic concretes at elevated temperatures", Cement and Concrete Research 31: 1291-1300, 2001.

5. M. Li, C. X. Qian, W. Sun, "Mechanical properties of high-strength concrete after fire", Cement and Concrete Research 34: 1001-1005, 2004.

6. J. Z. Xiao, G. Konig, "Study on concrete at high temperature in China-an overview", Fire Safety Journal 39: 89-103, 2004.

7. Y. F. Chang, Y. H. Chen, M. S. Sheu, G. C. Yao, "Residual stress-strain relationship for concrete after exposure to high temperatures", Cement and Concrete Research 36: 1999-2005, 2006.

8. M. Husem, "The effects of high temperature on compressive and flexural strengths of ordinary and highperforce concrete", Fire Safety Journal 41: 155-163, 2006.

9. B. Chen, C. L. Li, L. Z. Chen, "Experimental study of mechanical properties of normal-strength concrete exposed to high temperatures at an early age", Fire Safety Journal 44: 997-1002, 2009.

10. Z. J. He, Y. P. Song, "Multiaxial tensile-compressive strengths and failure criterion of plain high-performance concrete before and after high temperatures", Construction and Building Materials 24: 498-504, 2010.

11. Y. S. Tai, H. H. Pan, Y.N. Kung, "Mechanical properties of steel fiber reinforced reactive powder concrete following exposure to high temperature reaching $800^{\circ} \mathrm{C}$ ", Nuclear Engineering and Design 241: 2416-2424, 2011. 
12. W. Z. Zheng, H. Y. Li, Y. Wang, "Compressive stress-strain relationship of steel fiber-reinforced reactive powder concrete after exposure to elevated temperatures", Construction and Building Materials 35: 931-940, 2012.

13. B. Luigi, D. L. Giovanni, F. B. Joseph, "Mechanical properties of photocatalytic white concrete subjected to high temperatures", Cement and Concrete Composites 39: 73-81, 2013.

14. A. M. Marques, J. R. Correia, J. D. Brito, "Post-fire residual mechanical properties of concrete made with recycled rubber aggregate", Fire Safety Journal 58: 49-57, 2013.

15. K. E. Tahir, "Specimen size effect on the residual properties of engineered cementitious composites subjected to high temperatures", Cement and Concrete Composites 45: 1-8, 2014.

16. Z. W. Li, J. Y. Xu, E. L. Bai, "Static and dynamic mechanical properties of concrete after high temperature exposure", Materials Science and Engineering A 544: 27-32, 2012.

17. J. S. Huo, Y. M. He, L. P. Xiao, B. S. Chen, "Experimental study on dynamic behaviours of concrete after exposure to high temperatures up to $700^{\circ} \mathrm{C}$ ", Materials and Structures 46: 255-265, 2013.

18. H. Y. Su, J. Y. Xu, W. B. Ren, "Experimental study on the dynamic compressive mechanical properties of concrete at elevated temperature", Materials and Design 56: 579-588, 2014.

19. L. L. Shi, L. C. Wang, Y. P. Song, L. Shen, "Dynamic multiaxial strength and failure criterion of dam concrete", Construction and Building Materials 66: 181-191, 2014.

\section{LIST OF FIGURES AND TABLES:}

Fig. 1. The change of appearance characteristics of specimen after $200^{\circ} \mathrm{C}$

Rys. 1. Zmiana charakterystycznych cech wyglądu próbek po poddaniu ich temperaturze $200^{\circ} \mathrm{C}$

Fig. 2. The change of appearance characteristics of specimen after $400^{\circ} \mathrm{C}$

Rys. 2. Zmiana charakterystycznych cech wyglądu próbek po poddaniu ich temperaturze $400^{\circ} \mathrm{C}$

Fig. 3. The change of appearance characteristics of specimen after $600^{\circ} \mathrm{C}$

Rys. 3. Zmiana charakterystycznych cech wyglądu próbek po poddaniu ich temperaturze $600^{\circ} \mathrm{C}$

Fig. 4. The change of appearance characteristics of specimen after $800^{\circ} \mathrm{C}$

Rys. 4. Zmiana charakterystycznych cech wyglądu próbek po poddaniu ich temperaturze $800^{\circ} \mathrm{C}$

Fig. 5. The contrast of ultrasonic wave velocities of specimens between before and after high temperature

Rys. 5. Różnice w prędkości fal ultradźwiękowych w próbkach przed i po poddaniu ich działaniu wysokich temperatur

Fig. 6. The evolution of damage index

Rys. 6. Ewolucja wskaźnika uszkodzeń

Fig. 7. The evolution of mass loss of concrete specimen with temperature

Rys. 7. Ewolucja ubytku masy próbek w miarę wzrostu temperatury

Fig. 8. The influence of strain rate on the stress-strain curve of specimen when the temperature is the same

Rys. 8. Wpływ wskaźnika naprężeń na krzywą naprężenia i odkształcenia próbki przy tej samej temperaturze

Fig. 9. The influence of temperature on the stress-strain curve of specimen when the strain rate is the same

Rys. 9. Wpływ temperatury na krzywą naprężenia i odkształcenia próbki przy tym samym wskaźniku naprężeń

Fig. 10. The evolution of compressive strength

Rys. 10. Ewolucja wytrzymałości na ściskanie 
Fig. 11. Relation between strength increasing factor and stain-rate

Rys. 11. Zależność pomiędzy współczynnikiem wzrostu wytrzymałości a wskaźnikiem naprężeń

Fig. 12. The evolution of peak strain

Rys. 12. Ewolucja szczytowej wartości naprężenia

Fig. 13. The evolution of elastic modulus

Rys. 13. Ewolucja modułu sprężystości

Tab. 1. Mixtures of concrete specimens

Tab. 1. Mieszanki próbek betonu

Tab. 2. The number of samples before high temperature and the number of samples which had surface cracks after high temperature

Tab. 2. Liczba próbek przed poddaniem wysokiej temperaturze a liczba próbek ze spękaniami powierzchniowymi po poddaniu wysokiej temperaturze

Tab. 3. The distribution of ultrasonic wave velocities of specimens before high temperature

Tab. 3. Rozkład prędkości fal ultradźwiękowych w próbkach przed poddaniem ich wysokiej temperaturze 


\section{DYNAMICZNE WŁAŚCIWOŚCI MECHANICZNE BETONU DO OBUDOWY TUNELI W STANIE UMIARKOWANEGO - NISKIEGO NAPRĘŻENIA JEDNOOSIOWEGO PO ZASTOSOWANIU WYSOKICH TEMPERATUR}

Slowa kluczowe: beton, wysoka temperatura, wskaźnik naprężenia, właściwości mechaniczne

\section{STRESZCZENIE:}

Odporność ogniowa to jedno z najistotniejszych zagadnień, jakie należy brać pod uwagę przy projektowaniu tunelu. Testowanie właściwości mechanicznych betonu po pożarze stało się, jak dotąd, przedmiotem wielu projektów badawczych. Jakkolwiek powstały liczne publikacje na temat właściwości mechanicznych betonu w trakcie oraz po poddaniu go działaniu wysokich temperatur, niewiele uwagi poświęcono jak dotąd dynamicznym właściwościom mechanicznym betonu w trakcie lub po takim oddziaływaniu.

W przypadku wielu konstrukcji betonowych takich, jak tunele czy budynki, oczekuje się, że po pożarze będą one nadal pełniły swoją funkcję. Konstrukcje te mogą być też narażone na obciążenia sejsmiczne w trakcie okresu użytkowania. Dlatego też konieczne jest studiowanie dynamicznych właściwości mechanicznych betonu w trakcie lub po ekspozycji na działanie wysokich temperatur.

Aby przeanalizować właściwości mechaniczne betonowych okładzin tunelowych w stanie zróżnicowanego naprężenia od umiarkowanego do niskiego po oddziaływaniu wysokich temperatur, przeprowadzono testy naprężenia jednoosiowego w połączeniu z badaniami ultradźwiękowymi.

Klasa wytrzymałości betonu na ściskanie w przypadku wykorzystanych próbek to C40. Próbki poddawano oddziaływaniu szczytowych temperatur, wynoszących $200,400,600$ i $800^{\circ} \mathrm{C}$.

W ramach testów naprężenia jednoosiowego zastosowano cztery wskaźniki naprężenia, tj.: 10-2s-1, 10-3s-1, 10-4s-1 oraz $10-5 \mathrm{~s}-1$.

Wyniki testów przeanalizowano w odniesieniu do następujących właściwości:

(1) zmiana charakterystycznych cech wyglądu próbek,

(2) zmiana prędkości fal ultradźwiękowych w próbkach,

(3) zmiana ubytku masy,

(4) zróżnicowanie krzywych naprężenia i odkształcenia,

(5) ewolucja wytrzymałości na ściskanie,

(6) ewolucja szczytowej wartości naprężenia,

(7) ewolucja modułu sprężystości. 